\title{
THE DIVERSITY OF HALOTOLERANT AND HALOPHILIC BACTERIA IN THE SOIL OF THE NASINUAN SECONDARY FOREST IN MAHA SARAKHAM, THAILAND
}

\author{
CHOOKIETWATTANA KANNIKA* AND YUWA-AMORNPITAK THALISA
}

The Department of Biotechnology, Faculty of Technology, Mahasarakham University, Thailand.

*Corresponding author: kannika.c@msu.ac.th

Submitted final draft: 3 September $2020 \quad$ Accepted: 11 September $2020 \quad$ http://doi.org/10.46754/jssm.2021.02.017

\begin{abstract}
In the present study, we investigated the diversity of halotolerant and halophilic bacteria in the soil of the Nasinuan Secondary Forest using the culturable approach. Halotolerant, slightly halophilic, and moderately halophilic bacteria were isolated from soil samples using the halobacteria medium containing $0 \%, 3 \%$, and $6 \%$ w/v sodium chloride, respectively. In total, 55 isolates were obtained. A decreasing trend of bacterial diversity was found with the increase in concentration of sodium chloride in the medium. From a comparison of cell and colony morphologies, 16 isolates were selected for identification based on 16S rDNA sequence analysis. Of the 16 isolates, 14 isolates were halotolerant bacteria and 2 isolates were slightly halophile. Many of them had an ability to grow in a wide range of $\mathrm{NaCl}(0-8 \% \mathrm{w} / \mathrm{v})$. The 16 isolates belonged to 5 genera, namely Bacillus, Enterobacter, Janibacter, Rhodococcus, and Staphylococcus. The dominant species belonged to the genus Bacillus. The phylogenetic analysis showed genetic diversity covering 5 clusters: Gram-negative rods; Gram-positive rods/cocci, nonendospore-forming; Bacillus sensu stricto; Bacillus sensu lato; and Gram-positive cocci. This is the first comprehensive study of culturable halotolarant and halophilic bacterial diversity in a non-saline soil of Thailand.
\end{abstract}

Keywords: Bacterial diversity, bacterial flora, soil bacteria, saline soil, salt-affected areas.

\section{Introduction}

Soil salinization is one of the most crucial problems of arid and semiarid regions (Sakadevan, \& Nguyen, 2010). High salinity results in the reduction of crop productivity and quality (Yamaguchi \& Blumwald, 2005; Szabados et al., 2011). In Thailand, the majority of saline soil is in the northeast region, especially in Maha Sarakham Province, where $85 \%$ of the area is underlain by the rock salt strata (Wongsomsak, 1986). The moderately and heavily salt-affected areas have been found in almost the entire province (Ghassemi et al., 1995), except for the Nasinuan Secondary Forest.

Halotolerant and halophilic bacteria are microorganisms that thrive in saline environments (Javor, 1989; Oren, 2002; Maheshwari, \& Saraf, 2015). They have attracted much attention because their physiological properties can facilitate their exploitation for commercial and agricultural purposes (Kushner, 1993; Azua-
Bustos \& González-Silva, 2014; Singh, 2016; Waditee-Sirisattha et al., 2016). Early and intensive studies of bacterial diversity in saline environments were conducted in salt lakes and salterns (Litchfield \& Gillevet, 2002; Hacêne et al., 2004; Hedi et al., 2009; Vahed et al., 2011). Most studies of halophilic bacteria in Thailand deal with Thai fish sauce and salted foods, while the studies of saline soils are still limited (Tanasupawat et al., 2006; Chamroensaksri et al., 2010; Sumpavapol et al., 2010). In addition, soil bacteria are the primary organisms that drive the forest ecological processes (Felsmann et al., 2015) and their applications in sustainable agriculture are very successful and acceptable (Cavaglieri et al., 2005; Yadav \& Saxena, 2018). The knowledge regarding halophilic bacterial diversity in the Nasinuan Secondary Forest could provide baseline information for the reclamation of saline soil and the sustainability of the forest ecosystem and agricultural production. It was thus aimed in this work to explore the diversity of halotolerant and halophilic bacteria in the 
Nasinuan Secondary Forest and to obtain halotolerant and halophilic bacterial resources for future applications.

\section{Materials and Methods}

\section{Site Description and Soil Sample Collection}

The Nasinuan Secondary Forest is situated in Kantharawichai District, Maha Sarakham Province, Thailand, with a total area of approximately 19.2 hectares. The weather of the study area is tropical savanna. The sampling sites were divided into 14 plots, according to a previous study (Chookietwattana \& Yuwaamornpitak, 2019). Soil samples were collected seasonally between June 2017 and March 2018. The samples were randomly taken from three subplots for each plot at a depth of $30 \mathrm{~cm}$ using a hand auger. Samples from the same plot were mixed thoroughly. Then, one kilogram of the soil samples was taken and analysed within 24 hours.

\section{Isolation of Halophilic Bacteria from Soil Samples}

The halobacteria medium (Atlas, 1997) containing $0 \%, 3 \%$, and $6 \% \mathrm{w} / \mathrm{v} \mathrm{NaCl}$ were used for the isolation of halotolerant bacteria, slightly halophilic bacteria, and moderately halophilic bacteria according to the classification of microorganisms in response to salt $(\mathrm{NaCl})$ in which they grow best (Kushner, 1993). The $\mathrm{pH}$ of the medium was 7.2, unless otherwise stated. Ten-fold serial dilutions of the soil samples were made using a sterile normal saline solution, and $0.1 \mathrm{~mL}$ of each was spread out over the isolation medium. The plates were incubated for 2 to 3 days at $37^{\circ} \mathrm{C}$. Each different colony type (according to size, color, edge, and texture) in each plate was picked and streaked on the halobacteria medium containing $\mathrm{NaCl}$ at the same concentration as they were first isolated to obtain single colonies. This procedure was repeated to purify the isolates. All bacterial isolates were maintained on halobacteria agar slants for short-term applications and preserved in $50 \%$ glycerol stocks at $-70^{\circ} \mathrm{C}$ for long-term applications.

\section{Phenotypic and Genotypic Characterization of Bacterial Isolates}

The phenotypic characteristics of halophilic bacterial isolates, namely colony morphology (evaluated from first picked colonies from the original soil dilution plate), Gram-staining reaction, and cell morphology were examined. All bacterial isolates were classified on the basis of their response to salt $(\mathrm{NaCl})$ in which they grow best (Kushner, 1993). Bacterial growth at various $\mathrm{NaCl}$ concentrations $(0,3,8,15$, $20,25$, and $32 \% \mathrm{w} / \mathrm{v}), \mathrm{pH}(4,5,7,9$, and 11$)$, and temperatures $\left(10,25,35,45\right.$, and $\left.50^{\circ} \mathrm{C}\right)$ was determined by transferring $0.1 \mathrm{~mL}$ of preculture (approximate $10^{8} \mathrm{CFU} / \mathrm{mL}$ ) to $4.0 \mathrm{~mL}$ of halobacteria broth. Growth was determined by measuring an optical density at wavelengths of $600 \mathrm{~nm}$ after 48 hours of incubation. An optical density of below 0.05 meant that there were no growth and the highest optical density meant that the culture medium had an optimum condition for growth. For testing growth at various $\mathrm{NaCl}$ concentrations, the $\mathrm{pH}$ of the culture medium was fixed at 7.2 and the incubation temperature was kept at $37^{\circ} \mathrm{C}$. For testing growth at various $\mathrm{pH}$, the medium containing $\mathrm{NaCl}$ at an optimum concentration of each isolate was used and the incubation temperature was kept at $37^{\circ} \mathrm{C}$. For testing growth at various temperatures, the medium was kept at a $\mathrm{pH}$ level of 7.2 and $\mathrm{NaCl}$ at the optimum concentration of each isolate was used.

For genotypic characterization, genomic DNA was extracted using an InstaGene Matrix kit (Bio-Rad Laboratories, USA) according to the manufacturer's instructions. The 16S rRNA genes of bacterial isolates were amplified by PCR using primers 27F 5'(AGAGTTTGATCMTGGCTCAG)3' and 1492R 5'(TACGGYTACCTTGTTACGACTT)3'. The PCR reaction was performed with $20 \mathrm{ng}$ of genomic DNA as the template in a $30 \mu \mathrm{L}$ reaction mixture by using a EF-Taq (SolGent, Korea) as follows: initial denaturation at $95^{\circ} \mathrm{C}$ for 2 minutes, followed by 35 cycles of $95^{\circ} \mathrm{C}$ for 1 minutes, $55^{\circ} \mathrm{C}$, and $72^{\circ} \mathrm{C}$ for 1 minutes, and extension at $72^{\circ} \mathrm{C}$ for 10 minutes. The 
amplification products were purified with a multiscreen filter plate (Millipore Corp., Bedford, MA, USA). Sequencing reaction was performed using a PRISM BigDye Terminator v3.1 Cycle sequencing Kit. The sequencing primers were 785F 5' (GGATTAGATACCCTGGTA) 3' and 907R 5'(CCGTCAATTCMTTTR AGTTT)3'. The DNA samples containing the extension products were added to $\mathrm{Hi}-\mathrm{Di}$ formamide (Applied Biosystems, Foster City, CA). The mixture was incubated at $95^{\circ} \mathrm{C}$ for 5 minutes, followed by 5 minutes on ice and then analyzed by ABI Prism 3730XL DNA analyzer (Applied Biosystems, Foster City, CA). The 16S rRNA gene sequences were aligned to the nucleotides database provided by the National Center for Biotechnology Information (NCBI, U.S.A.) using the BLASTN (Basic Local Alignment Search Tools) (Altschul et al., 1990). The alignment scores and the percent sequence identity were determined for the closest identity. A multisequence alignment was performed using Clustal W. A phylogenetic tree was constructed by the neighbor-joining method using MEGA 6.0 (Tamura et al., 2013) with 1,000 bootstrap replications.

\section{Results and Discussion}

\section{Isolation of Bacteria from Soil Samples and Phenotypic Characterization}

The present study is the first report on halotolerant and halophilic bacterial diversity in the Nasinuan Secondary Forest, a non-salt affected area of Maha Sarakham. Forty-two soil samples were collected seasonally throughout the year and subjected for isolation of halotolerant and halophilic bacteria. It is worth mentioning that halotolerant bacteria grow best at $<1 \% \mathrm{w} / \mathrm{v}$ salt and can tolerate high salt, whereas halophile bacteria require high salt for growth (Kushner, 1993). Halophilic bacteria are divided into several groups according to salt concentrations in which they grow best. The slightly and moderately halophilic bacteria are defined as bacteria that grow best at $1-3 \%$, and $3-15 \% \mathrm{w} / \mathrm{v} \mathrm{NaCl}$, respectively. As such, the halobacteria media with the final $\mathrm{NaCl}$ concentration at $0 \%, 3 \%$, and $6 \% \mathrm{w} / \mathrm{v} \mathrm{NaCl}$ were used for the isolation of halotolerant, slightly halophilic, and moderately halophilic bacteria. Of the 55 bacterial isolates obtained, the 31,17 , and 7 isolates were isolated from the halobacteria media containing $0 \%, 3 \%$, and $6 \% \mathrm{w} / \mathrm{v} \mathrm{NaCl}$, respectively. These results are in agreement with the findings of Del Moral et al. (1987) and Ventosa et al. (1998), who found that bacterial diversity decreased as the salt concentration of the media increased.

The results of Gram-staining reaction of the 55 isolates revealed that most of them were Gram-positive bacteria (Figure 1). These results agreed with the study by Schimel et al. (2007). The soil texture as the loamy sand - sandy loam of the soil samples (Chookietwattana \& Yuwaamornpitak, 2019) caused inconsistent change in soil moisture content, soil $\mathrm{pH}$, soil salinity, and soil temperature by permitting rapid movements of materials moving through it, including air, water, and microorganisms (Rodriguez-Valera et al., 1981). The Gram-positive bacteria can better tolerate such a fluctuating environment compared with the Gram-negative bacteria as they have the stronger cell walls (Schimel et al., 2007). The teichoic acids found in the cell walls of Gram-positive bacteria provide the negative charges of the cell surface as a whole, thus increasing the mobility and transport of these bacteria in the environment. These findings may also be due to an extremely low amount of soil organic matter and total nitrogen in the soil samples (Chookietwattana \& Yuwa-amornpitak, 2019) since Gram-positive bacteria are more prevalent in soil of low quality, while Gramnegative bacteria dominates in soils of higher quality (Zhou et al., 2017). A total of 50 out of the 55 isolates were Gram-positive rods and endospore-forming. These results could be due to the fact that spore-forming bacteria are likely to be widely dispersed by wind and migratory birds (Jones et al., 1998). The ability to produce spores helps these bacteria endure and survive in arid environments with nutrients for low growth (Reynolds \& Pepper, 2000).

From the preliminary phenotypic observation (data not shown), 16 out of the 55 


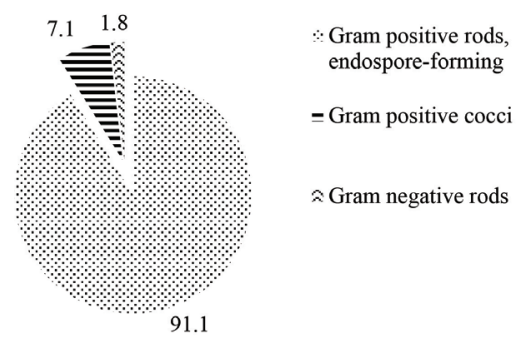

Figure 1: The results of microscopic observation of the Gram test

isolates were selected for further characterization. Although we specified the salt concentrations of the media to provide the optimal saline conditions for each halophilic bacterial group, we found that many isolates, especially the ones that were isolated from the medium containing either $3 \%$ or $6 \% \mathrm{w} / \mathrm{v} \mathrm{NaCl}$, could not grow in the media containing the same $\mathrm{NaCl}$ content. This is due to the fact that the halotolerants occupy the more diverse groups than those that tolerate only a small concentration $(1 \% \mathrm{w} / \mathrm{v})$ to a high concentration (up to saturation) of salt (Larsen, 1986). Therefore, to eliminate the taxonomic problems with halophiles, growth in response to salt was determined. The bacterial growth at various $\mathrm{pH}$ and temperature levels was also determined. The responses of bacterial isolates to salt $(\mathrm{NaCl}), \mathrm{pH}$, and temperature were summarized in Table 1. Quesada et al. (1982), Rodriguez-Valera et al. (1981) and Zahran et al.

Table 1: The characteristics of 16 isolates in response to salt, $\mathrm{pH}$, and temperature levels

\begin{tabular}{lccccccc}
\hline Isolate code & $\begin{array}{c}\text { Degree of } \\
\text { halophilia* }\end{array}$ & $\begin{array}{c}\text { NaCl } \\
\text { range }\end{array}$ & $\begin{array}{c}\text { Optimal } \\
\text { NaCl }\end{array}$ & $\begin{array}{c}\text { pH } \\
\text { range }\end{array}$ & $\begin{array}{c}\text { Optimal } \\
\text { pH }\end{array}$ & $\begin{array}{c}\text { Temperature } \\
\text { range }\end{array}$ & $\begin{array}{c}\text { Optimal } \\
\text { temperature }\end{array}$ \\
\hline 1. RSPG 10at & Halotolerant & $0-3$ & 0 & $5-9$ & 7 & $25-50$ & 50 \\
2. RSPG 1A & Halotolerant & $0-8$ & 0 & $5-9$ & 7 & $25-35$ & 25 \\
3. RSPG 2d & Halotolerant & $0-3$ & 0 & $7-9$ & 9 & $35-50$ & 50 \\
4. RSPG 8aad & Halotolerant & $0-3$ & 0 & $7-9$ & 9 & $25-35$ & 35 \\
5. RSPG 1N & Halotolerant & $0-8$ & 0 & $4-9$ & 7 & $25-50$ & 50 \\
6. RSPG 3h & Halotolerant & $0-3$ & 0 & $4-9$ & 7 & $25-35$ & 35 \\
7. RSPG 1T & Halotolerant & $0-3$ & 0 & $5-7$ & 7 & $35-50$ & 50 \\
8. RSPG 10t & Halotolerant & $0-3$ & 0 & $5-9$ & 9 & $25-50$ & 50 \\
9. RSPG 8k & Slightly & $0-8$ & 3 & $5-9$ & 7 & $25-50$ & 35 \\
10. RSPG 10am & Halophile & & & & & & \\
11. RSPG 3m & Slightly & $0-8$ & 3 & $7-9$ & 7 & $25-50$ & 35 \\
12. RSPG 15ac & Halotolerant & $0-8$ & 0 & $5-9$ & 5 & $25-50$ & 45 \\
13. RSPG 5ag & Halotolerant & $0-3$ & 0 & 7 & 7 & $25-50$ & 35 \\
14. RSPG 12f & Halotolerant & $0-3$ & 0 & $4-9$ & 5 & $25-45$ & 45 \\
15. RSPG 15aa & Halotolerant & $0-3$ & 0 & $5-9$ & 9 & $25-35$ & 35 \\
16. RSPG 7aac & Halotolerant & $0-3$ & 0 & $5-9$ & 7 & $35-50$ & 35 \\
\hline
\end{tabular}

*The degree of halophilic was interpreted by comparison with the classification of microorganisms' response to salt (NaCl) as described by Kushner (1993). 
(1992) reported that the majority of microflora in saline soil was halotolerant, while Echigo et al. (2005) found numerous halotolerant bacteria from non-saline soil. Thus, it is not surprising that soil samples that were non-saline (electrical conductivity ranging from $0.03-0.08 \mathrm{dS} / \mathrm{m}$, data not shown) showed mostly halotolerant bacteria, instead of halophilic bacteria. Only two slightly halophile bacteria were found and optimally grew at $3 \% \mathrm{w} / \mathrm{v} \mathrm{NaCl}$. The majority of isolates showed optimal growth at a $\mathrm{pH}$ level of 7 and temperature of $35^{\circ} \mathrm{C}$, which is the most favorable level for common bacteria. The upper limit of $\mathrm{NaCl}$ concentration permitting growth for many isolates obtained in this study was up to $8 \% \mathrm{w} / \mathrm{v}$ $\mathrm{NaCl}$.

\section{Genotypic Characterization of Bacterial Isolates}

To provide a more reliable classification, the genotypic characterization was performed with the help of phenotypic data. Sequences of PCR- amplified 16S rRNA genes of the 16 isolates were analysed (about 1,400 nucleotides). All 16S rRNA gene sequences of the isolates were compared with the nucleotide sequence database and deposited in the GenBank. The results of the search are summarized in Table 2. Sixteen isolates exhibited similarities higher than $99 \%$ with Bacillus (11 isolates), Staphylococcus (2 isolates), Enterobacter (1 isolate), Janibacter (1 isolate), and Rhodococcus (1 isolate). These results are similar to the findings of Echigo et al. (2005), who found that the Bacillus was a predominant genus in non-saline soil.

From the phylogenetic analysis, the isolates were divided into five clusters, as shown in Figure 2. The Gram-negative rods group was assigned to Cluster I, which comprised only one isolates related to Enterobacter hormaechei. Cluster II consisted of Janibacter anophelis and Rhodococcus rhodochrous, which exhibiting Gram-stain-positive to Gram-stain-variable

Table 2: Summary of information of the 16S rDNA sequence comparison

\begin{tabular}{|c|c|c|c|}
\hline \multirow[t]{2}{*}{ Isolate code } & \multirow[t]{2}{*}{ Closest relative } & \multicolumn{2}{|c|}{$\begin{array}{c}\text { Information of organisms used for sequences } \\
\text { comparison }\end{array}$} \\
\hline & & Accession number & Reference \\
\hline 1. RSPG 10at & Bacillus australimaris & JX680098 & Liu et al. (2013) \\
\hline 2. RSPG 1A & Bacillus cereus & NR074540 & Ivanova et al. (2003) \\
\hline 3. RSPG 2d & Bacillus glycinifermentans & КT005408 & Kim et al. (2015) \\
\hline 4. RSPG 8aad & Bacillus indicus & NR029022 & Suresh et al. (2004) \\
\hline 5. RSPG $1 \mathrm{~N}$ & Bacillus licheniformis & NR118996 & Ludwig et al. (1992) \\
\hline 6. RSPG 3h & Bacillus megaterium & СР009920 & Johnson et al. (2015) \\
\hline 7. RSPG $1 \mathrm{~T}$ & Bacillus subtilis & CP002905 & Earl et al. (2012) \\
\hline 8. RSPG $10 \mathrm{t}$ & Bacillus paralicheniformis & KY694465 & Dunlap et al. (2016) \\
\hline 9. RSPG 8k & Bacillus safensis & NR041794 & Venkateswaran et al. (2001) \\
\hline 10. RSPG 10am & Bacillus siamensis & KY643639 & Gondil et al. (Unpublished) \\
\hline 11. RSPG 3m & Bacillus wiedmannii & KU198626 & Miller et al. (2016) \\
\hline 12. RSPG $15 \mathrm{ac}$ & Enterobacter hormaechei & СР017179 & Chavda et al. (2016) \\
\hline 13. RSPG 5ag & Janibacter anophelis & NR043218 & Kämpfer et al. (2006) \\
\hline 14. RSPG $12 \mathrm{f}$ & Rhodococcus rhodochrous & NR037023 & Rainey et al. (1995) \\
\hline 15. RSPG 15 aa & Staphylococcus gallinarum & NR028667 & Lambert et al. (1998) \\
\hline 16. RSPG 7aac & $\begin{array}{l}\text { Staphylococcus } \\
\text { saprophyticus }\end{array}$ & NR074999 & Kuroda et al. (2005) \\
\hline
\end{tabular}


and rod-coccus lifecycle (Rainey et al., 1995; Kämpfer et al., 2006). The evolutionary relationship of Clusters I and II was distant from any other cluster. The phylogenetic tree confirmed the genetic diversity of the Bacillus. In this study, we divided Bacillus into two clusters, namely Clusters III and IV based on the branching patterns. Cluster III contained six species, namely Bacillus australimaris, Bacillus safensis, Bacillus subtilis, Bacillus paralicheniformis, Bacillus licheniformis, and Bacillus glycinifermentans, which Bacillus subtilis and Bacillus licheniformis are representative species of the Bacillus sensu stricto, hence the cluster name. Cluster IV consisted of five species, namely Bacillus siamensis, Bacillus indicus, Bacillus megaterium, Bacillus cereus, and Bacillus wiedmannii, which Bacillus cereus was the well-known species in the Bacillus sensu lato group (Zeigler, \& Perkins, 2009). Cluster V consisted of the genus Staphylococcus, which is a sister group among the Gram-positive bacilli (Götz, et al. 2006). Since the Bacillus spp. are the most dominant group involved in lbiogeochemical cycling mainly mediated by their diverse physiological characteristics, a more comprehensive analysis of the structure of the Bacillus community is needed to understand their roles and dynamics in the natural soil system. Many Bacillus strains have a wide range of biotechnological applications in enzyme production, antibiotic production, biofertilizer, biocontrol, and bioremediation (Zeigler \& Perkins, 2009). Thus, several salt tolerant and thermotolerant Bacillus strains obtained from this study have potential future applications.

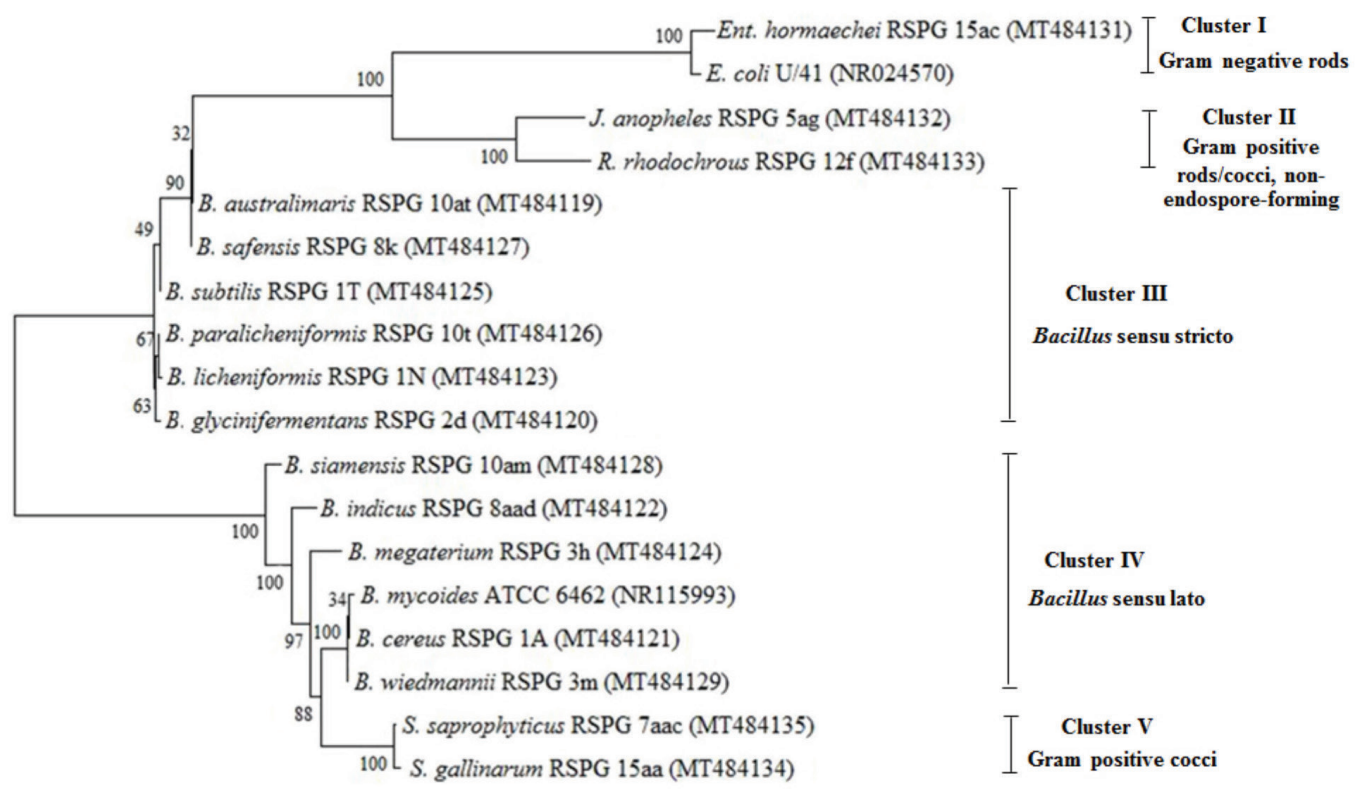

0.05

Figure 2: Neighbor-joining phylogenetic tree showing the relationships of the sixteen bacterial isolates obtained from the Nasinuan Secondary Forest. The GenBank accession numbers for all taxa are indicated in the parenthesis. E. coli strain U 5/41 (Cilia et al., 1996) and Bacillus mycoides strain ATCC 6462 (Soufiane, $\&$ Cote, unpublished) were used as reference strains for the Gram-negative and Gram-positive bacteria, respectively 


\section{Conclusion}

In the present study, we have demonstrated that the diverse taxa of halotolerant and halophilic bacteria thrive in non-saline soil. We could isolate 55 bacterial strains. Most of them were Gram-positive rods and endospore-forming, which belonged to the genus Bacillus. This study offers a promising start for understanding the bacterial communities inhabiting the secondary forest soil and also provides valuable microbial resources for biotechnological applications.

\section{Acknowledgements}

This work was financially supported by Mahasarakham University, Thailand (Year 2018), with the grant number $6105047 / 2561$.

\section{References}

Altschul, S. F., Gish, W., Miller, W., Myers, E. W., \& Lipman, D. J. (1990). Basic local alignment search tool. Journal of Molecular Biology, 215(3), 403-410. https://doi:10.1016/S0022-2836(05)803602.

Atlas, R. M. (1997). Handbook of Microbiological Media (2nd ed.). Boca Raton: CRC Press.

Azua-Bustos, A., \& González-Silva, C. (2014). Biotechnological applications derived from microorganisms of the Atacama Desert. BioMed Research International, 909312. https://doi. org/10.1155/2014/909312.

Cavaglieri, L., Orlando, J., Rodriguez, M. I., Chulze, S., \& Etcheverry, M. (2005). Biocontrol of Bacillus subtilis against Fusarium verticillioides in vitro and at the maize root level. Research in Microbiology, 156, 748-754. https://doi.org/10.1016/j. resmic.2005.03.001.

Chamroensaksri, N., Tanasupawat, S., Akaracharanya, A., Visessanguan, W., Kudo, T., \& Itoh.T. (2010). Gracilibacillus thailandensis sp. nov., from fermented fish (pla-ra). International Journal of Systematic and Evolutionary Microbiology, 60(4), 944-948. https://doi.org/10.1099/ ijs.0.011981-0.

Chavda, K. D., Chen, L., Fouts, D. E., Sutton, G., Brinkac, L., Jenkins, S. G., Bonomo, R. A., Adams, M. D., \& Kreiswirth, B. N. (2016). Comprehensive Genome Analysis of Carbapenemase-Producing Enterobacter spp.: New Insights into Phylogeny, Population Structure, and Resistance Mechanisms. MBio, 7(6), e02093-16. https://doi:10.1128/ mBio.02093-16.

Chookietwattana, K., \& Yuwa-amornpitak, T. (2019). Data on soil properties and halophilic bacterial densities in the Nasinuan Secondary Forest at Kantharawichai District, Maha Sarakham, Thailand. Data in Brief, 27, 104582. https://doi.org/10.1016/j. dib.2019.104582.

Cilia, V., Lafay, B., \& Christen, R. (1996). Sequence heterogeneities among 16S ribosomal RNA sequences, and their effect on phylogenetic analyses at the species level. Molecular Biology and Evolution, 13(3). 451461. https://doi.org/10.1093/oxfordjournals. molbev.a025606.

Del Moral, A., Quesada, E., \& RamosCormenzana, A. (1987). Distribution and types of bacteria isolated from an inland saltern. Annales de $l$ Institut Pasteur Microbiologie. 138(1), 59-66. https://doi.org/10.1016/0769-2609(87) 90054-8.

Dunlap, C. A., Kim, S. J., Kwon, S. W., \& Rooney, A. P. (2015). Bacillus velezensis is not a later heterotypic synonym of Bacillus amyloliquefaciens; Bacillus methylotrophicus, Bacillus amyloliquefaciens subsp. plantarum and 'Bacillus oryzicola' are later heterotypic synonyms of Bacillus velezensis based on phylogenomics. International Journal of Systematic and Evolutionary Microbiology, 66(3), 1212-1217. https://doi.org/10.1099/ ijsem.0.000858. 
Earl, A. M., Eppinger, M., Fricke, W. F., Rosovitz, M. J., Rasko, D. A., Daugherty, S., Losick, R., Kolter, R., \& Ravel, J. (2012). Whole-Genome Sequences of Bacillus subtilis and Close Relatives. Journal of Bacteriology, 194(9), 2378-2379. http://dx.doi.org/10.1128/JB.05675-11.

Echigo, A., Hino, M., Fukushima, T., Mizuki, T., Kamekura, M., \& Usa, R. (2005). Endospores of halophilic bacteria of the family Bacillaceae isolated from non-saline Japanese soil may be transported by Kosa event (Asian dust storm). Saline Systems, 1, 8. https://doi.org/10.1186/1746-1448-1-8.

Felsmann, K., Baudis, M., Gimbel, K., Kayler, Z.E., Ellerbrock, R., \& Bruehlheide, H. (2015). Soil bacterial community structure responses to precipitation reduction and forest management in forest ecosystems across Germany. PLoS One., 10, e0122539. https://doi.org/10.1371/journal. pone. 0122539

Ghassemi, F., Jakeman, A. J., \& Nix, H.A. (1995). Salanisation of Land and Water Resources. Wallingford Oxon: CAB International.

Götz, F., Bannerman, T., \& Schleifer, K. H. (2006). The Genera Staphylococcus and Macrococcus. In: Dworkin, M., Falkow, S., Rosenberg, E., Schleifer, K. H., Stackebrandt, E. (Eds.). The Prokaryotes (pp. 5-75). New York: Springer.

Hacêne, H., Rafa, F., Chebhouni, N., Boutaiba, S., Bhatnagar, T., Baratti, J.C., \& Ollivier, B. (2004). Biodiversity of prokaryotic microflora in El Golea Salt Lake, Algerian Sahara. Journal of Arid Environments, 58, 273-284. https://doi.org/10.1016/j. jaridenv.2003.08.006.

Hedi, A., Sadfi, N., Fardeau, M.-L., Rebib, H., Cayol, J. L., Ollivier, B. \& Boudabous, A. (2009). Studies on the biodiversity of halophilic microorganisms isolated from El-Djerid Salt Lake (Tunisia) under Aerobic Conditions. International Journal of Microbiology, 731786. https://doi. org/10.1155/2009/731786.
Ivanova, N., Sorokin, A., Anderson, I., Galleron, N., Candelon, B.,Kapatral, V., Bhattacharyya, A., Reznik, G., Mikhailova, N., Lapidus, A., Chu, L., Mazur, M., Goltsman, E., Larsen, N., D’Souza, M., Walunas, T., Grechkin, Y., Pusch, G., Haselkorn, R., Fonstein, M., Ehrlich, S. D., Overbeek, R., \& Kyrpides, N. (2003). Genome sequence of Bacillus cereus and comparative analysis with Bacillus anthracis, Nature, 423(6935), 87-91. https://doi.org/10.1038/nature01582.

Javor, B. (1989). Hypersaline environments, Microbiology and Biogeochemistry. Berlin: Springer-Verlag.

Johnson, S. L., Daligault, H. E., Davenport, K.W., Jaissle, J., Frey, K. G., Ladner, J. T., Broomall, S. M., Bishop-Lilly, K.A., Bruce, D. C., Gibbons, H. S., Coyne, S. R., Lo, C. C., Meincke, L., Munk, A. C., Koroleva, G. I., Rosenzweig, C. N., Palacios, G. F., Redden, C. L., Minogue, T. D., \& Chain, P. S. (2015). Complete Genome Sequences for 35 Biothreat Assay-Relevant Bacillus Species. Genome Announcements, 3(2), e00151-15. https://doi.org/10.1128/genomeA.00151-15.

Jones, B. E., W. D. Grant, A. W. Duckworth, \& G. G. Owenson. (1998). Microbial diversity of soda lakes. Extremophiles, 2, 191-200. https://doi.org/10.1007/s007920050060.

Kampfer, P., Terenius, O., Lindh, J. M., \& Faye, I. (2006). Janibacter anophelis sp. nov., isolated from the midgut of Anopheles arabiensis. International Journal of Systematic and Evolutionary Microbiology, 56(PT 2), 389-392. https://doi.org/10.1099/ ijs.0.63905-0.

Kim, S. J., Dunlap, C. A., Kwon, S. W., \& Rooney, A. P. (2015). Bacillus glycinifermentans sp. nov., isolated from fermented soybean paste, International Journal of Systematic and Evolutionary Microbiology, 65(10), 3586-3590. https://doi.org/10.1099/ijsem. 0.000462 . 
Kuroda, M., Yamashita, A., Hirakawa, H., Kumano, M., Morikawa, K., Higashide, M., Maruyama, A., Inose, Y., Matoba, K., Toh, H., Kuhara, S., Hattori, M., \& Ohta, T. (2005). Whole genome sequence of Staphylococcus saprophyticus reveals the pathogenesis of uncomplicated urinary tract infection. Proceedings of the National Academy of Sciences of the United States of America, 102(37), 13272-13277. https:// doi.org/10.1073/pnas.0502950102.

Kushner, D. J. (1993). Growth and nutrition of halophilic bacteria. In R. H. Vreeland, \& L. I. Hochstein (Eds.). The Biology of Halophilic Bacteria (pp. 87-89). Boca Raton: CRC Press.

Lambert, L. H., Cox, T., Mitchell, K., RosselloMora, R. A., Del Cueto, C., Dodge, D. E., Orkand, P., \& Cano, R. J. (1998). Staphylococcus succinus sp. nov., isolated from Dominican amber. International Journal of Systematic Bacteriology, 48(Pt 2), 511-518. https://doi.org/10.1099/00207713-48-2511.

Larsen, R. (1986). Halophilic and halotolerant microorganisms-an overview and historical perspective. FEMS Microbiology Reviews, 2(1-2), 3-7. https://doi. org/10.1111/j.1574-6968.1986.tb01835.x.

Litchfield, C. D., \& Gillevet, P. M. (2002). Microbial diversity and complexity in hypersaline environments, a preliminary assessment. Journal of Industrial Microbiology and Biotechnology.

Biotechnology, 28(1), 48-55. http://dx.doi. org $/ 10.1038 / \mathrm{sj} / \mathrm{jim} / 7000175$.

Liu, Y., Lai, Q., Dong, C., Sun, F., Wang, L., Li, G., \& Shao, Z. (2013). Phylogenetic diversity of the Bacillus pumilus group and the marine ecotype revealed by multilocus sequence analysis. PLoS One, 8(11), E80097. https://doi.org/10.1371/journal. pone.0080097.

Ludwig, W., Kirchof, G., Klugbauer, N., Weizenegger, M., Betzl, D., Ehrmann, M., Hertel, C., Jilg, S., Tatzel, R., Zitzelsberger, H.,
Liebl, S., Hochberger, M., Shah, J., Lane, D., \& Wallnoef, P.R. (1992). Complete 23S ribosomal RNA sequences of Gram-positive Bacteria with a low DNA G+C content. Systematic and Applied Microbiology, 15, 487-501. https://doi.org/10.1016/S07232020(11)80107-4.

Maheshwari, D. K., \& Saraf, M. (2015). Halophiles Biodiversity and Sustainable Exploitation. Cham: Springer.

Miller, R. A., Beno, S. M., Kent, D. J., Carroll, L. M., Martin, N. H., Boor, K. J., \& Kovac, J. (2016). Bacillus wiedmannii sp. nov., a psychrotolerant and cytotoxic Bacillus cereus group species isolated from dairy foods and dairy environments. International Journal of Systematic and Evolutionary Microbiology, 66(11), 4744-4753. https:// doi.org/10.1099/ijsem.0.001421.

Oren, A. (2002). Diversity of halophilic microorganisms, environments, phylogeny, physiology and applications. Journal of Industrial Microbiology and Biotechnology, 28(1), 56-63. https://doi.org/10.1038/sj/ $\mathrm{jim} / 7000176$.

Quesada, E., Ventosa, A., Rodriguez-Valera, F., \& Ramos-Cormenzana, A. (1982). Types and properties of some bacteria isolated from hypersaline soils. Journal of Applied Microbiology, 53, 155-161. https://doi. org/10.1111/j.1365-2672.1982.tb04671.x.

Rainey, F. A., Klatte, S., Kroppenstedt, R. M., \& Stackebrandt, E. (1995). Dietzia, new genus including Dietzia maris comb. nov., formerly Rhodococcus maris. International Journal of Systematic Bacteriology, 45(1), 32-36. https://doi.org/10.1099/0020771345-1-32.

Reynolds, K. A., \& Pepper, I. L. (2000). Microorganisms in the environment. In R. M. Maier, I. L. Pepper, \& C. P. Gerba (Eds.). Environmental Microbiology (pp. 7-41). San Diego: Academic Press.

Rodriguez-Valera, F., F. Ruiz-Berraquero, \& A. Ramos-Cormenzana. (1981). Characteristics 
of the heterotrophic bacterial populations in hypersaline environments of different salt concentrations. Microbial Ecology, 7, 235243. https://doi.org/10.1007/BF02010306.

Sakadevan, K., \& Nguyen, M. L. (2010). Chapter two - Extent, impact, and response to soil and water salinity in arid and semiarid regions. Advances in Agronomy, 109, 55-74. https://doi.org/10.1016/B9780-12-385040-9.00002-5.

Schimel, J., Balser, T. C., \& Wallenstein, M. (2007). Microbial stress-response physiology and its implications for ecosystem function. Ecology, 88, 13861394. https://doi.org/10.1890/06-0219.

Singh, K. (2016). Microbial and enzyme activities of saline and sodic soils. Land Degradation and Development, 27(3), 706-718. https://doi.org/10.1002/ldr.2385.

Sumpavapol, P., Tongyonk, L., Tanasupawat, S., Chokesajjawatee, N., Luxananil, P., \& Visessanguan, W. (2010). Bacillus siamensis sp. nov., isolated from salted crab (poo-khem) in Thailand. International journal of systematic and evolutionary microbiology, 60(1), 2364-2370. https:// doi.org/10.1099/ijs.0.018879-0.

Suresh, K., Prabagaran, S. R., Sengupta, S. and Shivaji, S. (2004). Bacillus indicus sp. nov., an arsenic-resistant bacterium isolated from an aquifer in West Bengal, India. International Journal of Systematic and Evolutionary Microbiology, 54(PT 4), 1369-1375. http://dx.doi.org/10.1099/ ijs.0.03047-0.

Szabados, L., Kovács, H., Zilberstein, A., \& Bouchereau, A. (2011). Chapter 4 - Plants in extreme environments: importance of protective compounds in stress tolerance. Advances in Botanical Research, 57, 105150. https://doi.org/10.1016/B978-0-12387692-8.00004-7.

Tamura, K., Stecher, G., Peterson, D., Filipski, A., \& Kumar, S. (2013). MEGA6: molecular evolutionary genetics analysis version 6.0.
Molecular Biology and Evolution, 30, 2725 -

2729. https://doi.org/10.1093/molbev/mst 197

Tanasupawat, S., Pakdeeto, A., Namwong, S., Thawai, C., Kudo, T., \& Itoh. T. (2006). Lentibacillus halophilus sp. nov., from fish sauce in Thailand. International journal of systematic and evolutionary microbiology, 56(8), 1859-1863. https://doi.org/10.1099/ ijs.0.63997-0.

Vahed, S. Z., Forouhandeh, H., Hassanzadeh, S, Klenk, H.-P., \& Mohammad Amin Hejazi, M.S.H. (2011). Isolation and identification of halophilic bacteria from Urmia Lake in Iran. Systematic and Applied Microbiology, 80, 834-841. https://doi.org/10.1134/ S0026261711060191,

Venkateswaran, K., Satomi, M., Chung, S., Kern, R., Koukol, R., Basic, C., \& White, D. (2001). Molecular microbial diversity of a spacecraft assembly facility. Systematic and Applied Microbiology, 24(2), 311-320. https://doi.org/10.1078/0723-2020-00018,

Ventosa, A., Carmen Márquez, M., Garabito, M. J., \& Arahal, D. R. (1998). Moderately halophilic gram-positive bacterial diversity in hypersaline environments. Extremophiles, 2(3), 297-304. https://doi. org/10.1007/s007920050072,

Waditee-Sirisattha, R., Kageyama, H. \& Takabe, T. (2016). Halophilic microorganism resources and their applications in industrial and environmental biotechnology. AIMS Microbiology, 2, 42-54. https://doi. org/10.3934/ microbiol.2016.1.42,

Wongsomsak, S. (1986). Salinization in Northeast Thailand. Southeast Asian Studies, 24(2), 133-153. http://hdl.handle. net/2433/56243.

Yadav, A. J., \& Saxena, A. K. (2018). Biodiversity and biotechnological applications of halophilic microbes for sustainable agriculture. Journal of Applied Biology and Biotechnology, 6(1), 48-55. https://dx.doi. org/10.7324/JABB.2018.60109. 
Yamaguchi T., \& Blumwald, E. Zeigler, D. R., \& Perkins, J. B. (2009). The (2005). Developing salt-tolerant genus Bacillus. In E. Goldman, \& L. crop plants: challenges and H. Green (Ed.). Practical Handbook of opportunities. Trends in Plant Microbiology (pp. 309-326). Boca Raton: Science, 10(12), 615-620. https://doi. org/10.1016/j.tplants.2005.10.002.

Zahran, H. H., Moharram, A. M., \& Mohammad, Zhou, Z., Wang, C., Jiang, L, \& Luo, Y. (2017). Trends in soil microbial communities during secondary succession. Soil Biology and Biochemistry, 115, 92-99. https://doi. org/10.1016/j.soilbio.2017.08.014. physiological studies on bacteria isolated from salt-affected soils of Egypt. Journal of Basic Microbiology, 32(6), 405-413. https:// doi.org/10.1002/jobm.3620320612. 